\title{
Implementasi Integrated Marketing Communications Vasektomi dalam Upaya Peningkatan Akseptor Kb Pria Lestari
}

\author{
Basuki $^{1}$, Panji Dwi Ashrianto ${ }^{2}$ \\ ${ }^{1,2}$ Program Studi Ilmu Komunikasi, Fakultas Ilmu Sosial dan Ilmu Politik, \\ Universitas Pembangunan Nasional "Veteran" Yogyakarta \\ Jl. Babarsari No. 2 Tambakbayan Yogyakarta, 55281, Indonesia \\ Email: panji_adver@yahoo.co.id ${ }^{2 *}$ \\ *Corresponding author
}

\begin{abstract}
KB Paradigm already shifting from population control and fertility decline to the health of reproduction by concerning about the rights of reproduction and gender equality. One of the attempt or effort is men participation in $\mathrm{KB}$ whether it is by condor or vasectomy. The socialization of $\mathrm{MOP}$ Method is not easy. Many contradictions come from both man and wife. Religion aspect also becomes one of consideration. The aim of this research is to discover the implementation of marketing communication of vasectomy method in Pekalongan. The research method is collecting data through observation. The research result shows that MOP socialisation was almost never been done before. There's also no amount of target of participants. KIE implementation by applying the marketing communication for MOP gains a better response from counselor team and society. GerebekPasar was effective to create public's opinion. GerebegPasar is a counseling held in public places such as market. Marketing team was equipped with brochures and loudspeaker to gain the response from market visitors. People were enthusiast and not hesitate to ask about MOP. Counseling also effective to create public opinion because it attended by clergy, doctors and MOP participants who give satisfying amount of information. Face to face communication were effective for behavioral change because each participant candidates could ask effectively. Motivation using persona creates linkage between the officer and MOP participant candidates. After this KIE activity, there are six couple who join this program. Keywords: GerebegPasar; Integrated Marketing Communication; Vasectomy
\end{abstract}

\begin{abstract}
Abstrak
Paradigma KB sudah bergeser dari pengendalian populasi dan penurunan fertilitas ke kesehatan reproduksi dengan memperhatikan hak reproduksi dan kesetaraan gender. Salah satu upaya atau upayanya adalah partisipasi laki-laki dalam KB baik itu dengan cara condor maupun vasektomi. Sosialisasi Metode MOP memang tidak mudah. Banyak kontradiksi datang dari suami dan istri. Aspek agama juga menjadi salah satu pertimbangan. Tujuan penelitian ini adalah untuk mengetahui implementasi komunikasi pemasaran metode vasektomi di Kota Pekalongan. Metode penelitian adalah pengumpulan data melalui observasi. Hasil penelitian menunjukkan bahwa sosialisasi MOP hampir tidak pernah dilakukan sebelumnya. Target peserta juga tidak ada. Penerapan KIE dengan menerapkan komunikasi pemasaran untuk MOP mendapatkan respon yang lebih baik dari tim konselor dan masyarakat. GerebekPasar efektif untuk menciptakan opini publik. GerebegPasar merupakan penyuluhan yang diadakan di tempat-tempat umum seperti pasar. Tim marketing dilengkapi dengan brosur dan loudspeaker untuk mendapatkan respon dari pengunjung pasar. Masyarakat sangat antusias dan tidak sungkan untuk bertanya tentang MOP. Penyuluhan juga efektif untuk menciptakan opini publik karena dihadiri oleh ulama, dokter dan peserta MOP yang memberikan informasi yang memuaskan. Komunikasi tatap muka efektif untuk perubahan perilaku karena setiap calon peserta dapat bertanya secara efektif. Motivasi menggunakan persona menciptakan keterkaitan antara petugas dan calon peserta MOP. Usai kegiatan KIE ini, ada enam pasangan yang mengikuti program ini. Kata kunci: Vasektomi; Komunikasi Pemasaran Terintegrasi; GerebegPasar
\end{abstract}

\section{Pendahuluan}

Pusat data informasi (Pusdatin) Kemenkes mengestimasi tahun 2013 menunjukkan bahwa jumlah penduduk Indonesia telah 248,4 juta jiwa berdasarkan angka fertilitas 2,6 per tahun. Angka fertilitas tersebut masih diatas rata- rata TFR (Total fertility Rate) ASEAN yaitu 2.4. Tingginya laju pertumbuhan penduduk tersebut juga diwarnai oleh penyebaran yang tidak merata, tingginya angka kemiskinan, akses kesehatan dan pendidikan yang rendah. 
Salah satu upaya untuk meningkatkan kesejahteraan (ekonomi, pendidikan, kesehatan) adalah penggalakan program keluarga berencana (KB). Seperti dinyatakan dalam Undang-Undang No. 52 tahun 2009 tentang Perkembangan Kependudukan dan Pembangunan Keluarga bahwa pembangunan keluarga adalah upaya mewujudkan keluarga berkualitas yang hidup dalam lingkungan yang sehat. Undang-Undang ini mendukung program $\mathrm{KB}$ sebagai salah satu upaya untuk mewujudkan keluarga sehat dan berkualitas.

Konferensi Internasional tentang Kependudukan dan Pembangunan tahun 1994 di Mesir telah menyepakati perubahan paradigma KB yaitu dari pengendalian populasi bergeser ke paradigma kesehatan reproduksi dengan memperhatikan hak-hak reproduksi dan kesetaraan gender. Paradigma baru ini menuntut kesadaran kaum laki-laki akan kewajibannya turut serta menjamin atau mewujudkan kesehatan reproduksi perempuan (istri).

Sejak saat itu kepesertaan KB oleh pria terus menggema. Di beberapa negara perkembangan kepersertaan $\mathrm{KB}$ pria cukup menggembirakan. Sebagai contoh di Malaysia tahun 1998 (16,8\%), Bangladesh tahun 1997 (13,9\%). Sedangkan sasaran KB pria di Indonesia tahun 2007 masih sekitar 4,5\% (Wahyuni, 2013:81).

Menurut dr. Widi Atmoko, perkembangan metode kontrasepsi pria cukup penting karena lebih dari $40 \%$ perempuan tidak mencapai target dalam program keluarga berencana. Sekitar 80 juta perempuan mengalami kehamilan yang tidak diinginkan setiap tahun. Kontrasepsi wanita banyak didominasi metode hormonal (suntik, pil atau oral). Sementara mereka tidak tertib yang pada akhirnya memicu laju pertumbuhan. Disamping itu kontrasepsi yang dipakai wanita kurang mendukung kesehatan reproduksi: seperti metode IUD dapat menimbulkan perdarahan, metode hormonal berpengaruh pada horman-horman lain dalam tubuh. Sementara vasektomi merupakan metode kontrasepsi yang efektif, mudah, cepat, dan aman. Selain itu kepesertaan vasektomi mendukung kesehatan reproduksi wanita (Atmoko, 2013).
Kepersertaan KB pria masih masih sangat rendah. Banyak faktor baik yang datang dari istri, suami, atau masyarakat, bahkan pemerintah. Banyak istri yang takut suaminya akan selingkuh jika ikut vasektomi. Sementara laki-laki (suami) takut kehilangan kejantanan, kenikmatan. Opini masyarakat masih negatif yaitu memahami vasektomi adalah dikebiri dan dilarang agama. Fatwa MUI melalui ijtima ulama ke IV 2012 di Tasikmalaya memutuskan bahwa vasektomi tidak halal secara mutlak. Artinya diperbolehkan jika tidak menyalahi syariat, tidak menimbulkan kemandulan permanen, ada jaminan dapat direkanalisasi kembali dan tidak membahayakan bagi yang bersangkutan. Paradigma baru program Keluarga Berencana Nasional telah berubah dari mewujudkan Norma Keluarga Kecil Bahagia Sejahtera (NKKBS) menjadi visi untuk mewujudkan "Mewujudkan Keluarga Berkualitas". Keluarga berkualitas adalah sejahtera, sehat, maju, mandiri, memiliki jumlah anak ideal, berwawasan ke depan, bertanggung jawab,harmonis, danbertaqwakepadaTuhanYang Maha Esa. Pencegahan kematian dan kesakitan merupakan alasan utama diperlukan pelayanan Keluarga Berencana. Salah satu pesan kunci dalam rencana strategi nasional adalah "Making Pregnancy Saver". Setiap kehamilan adalah kehamilan yang dinginkan dan direncanakan.

Partisipasi pria atau suami dalam KB adalah tangggung jawa pria atau suami dalam dalam meningkatkan kesehatan reproduksi wanita atau istri sekaligus mewujudkan keluarga berkualitas. Para pria atau suami harus ditumbuhkan kesadarannya bahwa akan tanggung jawabnya pada keberhasilan KB mereka dan tidak melempar tanggung jawab tersebut pada wanita/ istri mereka. Mereka harus sadar akan prinsip kesetaraan gender dalam ber-KB. Mereka harus sadar bahwa kaum wanita atau istri sudah menanggung beban luar biasa mulai dari hamil, melahirkan, menyususi, merawat anak-anak. Tidak sepantasnya jika penggunaaan metode kontrasepsi juga menjadi tanggung jawabnya. 
Sementara penggunaan metode kontrasepsi untuk wanita lebih beresiko pada kesehatan reproduksi daripada metode kontrasepsi pada kaum pria.

Beberapa penelitian menunjukkan bahwa pendidikan kesehatan berkorelasi positip terhadap penerimaan vasektomi (Hardiani,2013: Wahyuni,2013). Artinya informasi yang cukup tentang vasektomi telah merubah sikap tentang vasektomidanberujungpadapeningkatanakseptor vasektomi. Informasi yang cukup memadahi telah mampu merubah pandangan tentang vasektomi (sebagai metode yang positif). Untuk itu permasalahan yang muncul adalah bagaimana model Komunikasi Informasi Edukasi (KIE) yang tepat sehingga pesan penting vasektomi dapat diterima tanpa unsur keterpaksaan.

Ada dua kasus yang menarik tentang keberhasilan KIE vasektomi yaitu di Kota Surabaya dan di kabupaten Badung. Pemerintah Kota Surabaya mampu meraih MDGs Award tahun 2013 untuk kategori kesehatan reproduksi dengan program Keberhasilan pemerintah dalam membina kelompok Vasektomi. Di kabupaten Badung adabidan yang memperoleh penghargaan sebagai bidan teladan nasional karena ketekunannya sebagai penyemangat $\mathrm{KB}$ pria.

Dari hasil penelitian di dua lokasi tersebut diketahui bahwa untuk meningkatkan peserta jumlah peserta KB Pria Lestari mereka tidak mengandalkan satu bentuk komunikasi pemasaran saja. Mereka mengembangkan strategi alternatif lain dengan sangat kreatif yaitu memadukan seluruh bentuk komunikasi pemasaran. Hasilnya adalah opini publik tentang MOP terbentuk dan perubahan perilaku yang ditandai meningkatnya peserta KB Pria Lestari yang cukup signifikan. Model ini perlu diadopsi untuk daerah lain yang ingin meningkatkan jumlah peserta KB Pria Lestari.

Keberadaan kelompok KB Pria Lestari juga punya peran besar untuk menjadi daya tarik kepesertaan vasektomi. Aktifitas kelompok ini selain melakukan sosialisasi juga berbagai bantuan baik pelatihan maupun finansial telah menjadi daya tarik orang untuk mengapresiasi keberadaan kelompok ini. Paling tidak nama KB Lanang sudah familiar ditengah-tengah masyarakat Surabaya.

Pemberian uang saku dapat dijadikan daya tarik tersendiri yang dalam istilah komunikasi pemasaran disebut merchandise. Di Kota Surabaya, uang 100.000 rupiah ternyata menjadi daya tarik tersendiri yang dapat mengubah perilaku dengan cepat. Beberapa peserta vasektomi (KB Lanang) rela mengikuti vasektomi karena tergiur pemberian uang 100 ribu rupiah. Karakter peserta KB Lanang di Surabaya banyak dipengaruhi faktor kemiskinan. Di Kabupaten Badung diberikan uang saku sebesar 2.700.000 rupiah sebagai uang pengganti kerja karena mereka dalam beberapa hari pasca vasektomi diharuskan beristirahat total. Karakter peserta vasektomi di Badung banyak diwarnai kegagalan $\mathrm{KB}$ sang istri.

Kepesertaan vasektomi di Kota Pekalongan kecil sekali. Data BPS Jateng (jateng.bps.go.id) melaporkan bahwa jumlah akseptor vasektomi tahun 2014 Kota Pekalongan 111 (terendah ke dua setelah Kota Magelang). Prosentase dari peserta vasektomi di Jawa Tengah (52.296) yaitu sangat kecil sekali (0,002\%). Data BPMP2AKB (Badan Pemberdayaan Masyarakat Perempuan Perlindungan Anak dan Keluarga Berencana) Kota Pekalongan tahun 2015 perolehan peserta KB melampui target 113,6 \% (7.066 peserta dari target 6.250 peserta). Namun demikian dari jumlah tersebut peserta MOP (vasektomi) hanya 10 (http://m.beritasatu.com/ com/kesra. 24 januari 2016). Ini menunjukkan kepesertaan MOP sangat sangat rendah sekali.

Kota Pekalongan merupakan kota pesisir dimana banyak penduduknya yang bekerja sebagai nelayan. Ciri perkampungan nelayan adalah tingkat kelahiran tinggi, kumuh, dan identik dengan kemiskinan. Untuk itu pemerintah pekalongan menetapkan Kelurahan Bandengan sebagai kampung KB. Kelurahan tersebut betul-betul menggambarkan kampung nelayan syarat dengan ciri-cirinya. 
Setelah ditelusuri ada beberapa hal yang menyebabkan rendahnya kepesertaan MOP. 1). Kehalalan MOP menurut agama. Hal ini wajar karena Kota Pekalongan terkenal religius. 2) tidak ada upaya khusus dalam KIE MOP. Informasi KIE hanya disampaikan sekilas lewat penyuluhan sehingga opini publik tidak terbentuk. Bahkan masyarakat hampir tidak mengenal istilah vasektomi. Hal ini berbeda sekali dengan di Kota Surabaya. 3) KIE hanya dilakukan dengan face to face pada kasus-kasus khusus.

Penelitian ini mengujicobakan kasus keberhasilan KIE Vasektomi di Kota Surabaya dan Kabupaten Badung di Kota Pekalongan. Untuk itu permasalahan dalam penelitian ini dapat dirumuskan sebagai berikut: "Bagaimana efektifitas implementasi komunikasi pemasaran terpadu pada KIE (Komunikasi Informasi Edukasi) metode vasektomi sebagai upaya peningkatan akseptor KB Pria Lestari di Kota Pekalongan?"

Kajian Pustaka dilakukan untuk mengetahui roadmap penelitian KB pria vasektomi yang pernah dilakukan. Dengan demikian penelitian ini dapat mengambil celah pada bidang dan subyek ataupun tema yang belum pernah dilakukan. Atau bahkan penelitian dapat merupakan kelanjutan dari penelitianpenelitian sebelumnya. Kajian literatur dapat memperlihatkan posisi dari penelitian ini dari penelitian-penelitian yang sudah ada.

Penelitian terdahulu yang relevan dengan penelitian ini adalah penelitian Purwanti (2011) yang berjudul Upaya Peningkatan Partisipasi Pria Dalam Keluarga Berencana dan Kesehatan Reproduksi sebagai Wujud Kesetaraan Gender. Penelitian tersebut ditujukan untuk mendeskripsikan upaya-upaya pemerintah Kabupaten Lumajang dalam meningkatkan partisipasi pria dalam KB dan kesehatan reproduksi. Pendekatan yang digunakan adalah yuridis sosiologi (sociolegal research), yaitu tidak semata-mata mengkaji aturan tentang kesamaan hak dan kewajiban pria- wanita dalam KB dan kesehatan reproduksi, tetapi juga melihat langsung bagaimana kehidupan masyarakat sebenarnya.
Kesimpulan penelitian tersebut adalah partisipasi pria dalam mengikuti program KB hanya meningkat $0,4 \%$ (sangat minim). Laki-laki lebih menyerahkan pada pasangannya dalam merencakan program KB. Upaya yang dilakukan pemerintah Lumajang adalah sangat normatif yaitu mengkoordinasikan instansi terkait.

Penelitian ini juga relevan dengan penelitian Wahyuni (2013) berjudul hubungan Pengetahuan dan Sikap Akseptor KB Pria Tentang Vasektomi Serta Dukungan Keluarga dengan Partisipasi Pria dalam Vasektomi Di Kecamatan Tejakula Kabupaten Buleleng Penelitian tersebut dilatarbelakangi oleh rendahnya partisipasi pria sebagai akseptor vasektomi. Di sisi lain paradigma program KB sudah bergeser dari pengendalian populasi dan penurunan fertilitas ke pendekatan kesehatan reproduksi. Tujuan penelitian ini adalah untuk mengetahui pengaruh pengetahuan, sikap tentang vasektomi serta dukungan keluarga terhadap partisipasi pria dalam vasektomi. Metode yang digunakan adalah survai dengan jumlah sampel 87 dan analisis data menggunakan Regresi Logistik. Hasil penelitian tersebut menunjukkan bahwa pengetahua, sikap, dan dukungan keluarga berpengaruh signifikan terhap opartisipasi pria dalam vasektomi. Saran dari penelitian ini adalah petugas lapangan KB diharapkan agar lebih meningkatkan promosi pelayanan vasektomi melalui pemberian pendidikan KB dalam bentuk penyuluhan dan pendekatan keluarga mengenai pentingnya kontrasepsi vasektomi.

Penelitian ini relevan dengan peneltian Hardiani dan Pertiwi (2013) berjudul Pendidikan Kesehatan Terhadap Sikap Suami Tentang Vasektomi. Penelitian tersebut dilatarbelakangi oleh masih didominasinya penggunaaan kontrasepsi oleh kelompok wanita terutama kontrasepsi hormona. Padahal banyak dari mereka yang tidak patuh atruran penggunaan yang akhirnya dapat memicu ledakan penduduk. Tujuan dari penelitian tersebut adalah untuk mengetahui pengaruh pendidikan kesehatan 
terhadap sikap suami tentang vasektomi. Dengan metode survei yaitu menggunakan 92 sampel dan teknik analisis data uji Mann Whittney U Test diketahui bahwa 82,6\% dari kelompok suami memiliki sikap positip setelah pemberian intervensi pendidikan kesehatan tentang vasektomi. Saran dari peneltian ini adalah agar petugas kesehatan menerapkan dan mengembangkan program pendidikan kesehatan tentang vasektomi bagi suami.

Penelitian Sukeni (2009) yang berjudul Hegemoni Negara dan Resistensi Perempuan dalam Keluarga Berencana di Kecamatan Tejakula Kabupaten Buleleng Bali relevan dengan penelitian ini. Tujuan penelitian tersebut adalah untuk mengetahui kesetaraan gender dalam pelaksanaan program KB dalam meminimalkan efek samping bagi akseptor. Data digali dengan wawancara mendalam dan studi dokumen. Analisis data secara kualitatif. Hasil penelitian menyebutkan bahwa hegemoni negara telah mengantarkan program $\mathrm{KB}$ mencapai kesuksesan dalam upaya mengurangi jumlah penduduk secara bertahap dan telah berhasil mengubah pandangan masyarakat bahwa banyak anak banyak rejeki menjadi keluarga kecil yang berorientasi kepada sumberdaya yang berkualitas. Saran dari penelitian ini supaya program KB terus diperbaiki dalam upaya meminimalkan efek samping demi mewujudkan kesehatan keluarga serta kesetaraan gender dala akseptor KB.

Peneliti pernah melakukan penelitian sejenis Basuki dan Panji Dwi Ashrianto tahun 2015 yang berjudul Strategi Kreatif Komunikasi Informasi Edukasi (KIE) metode Vasektomi dalam Upaya Peningkatan Peserta KB Pria Lestari : Analisis Kasus di Kota Surabaya dan Kabupaten Badung. Tujuan dari penelitian tersebut adalah untuk mengetahui strategi KIE yang dikembangkan di kota Surabaya sehingga memperoleh MDGs Award 2013 kategori kesehatan ibu dan anak dengan program unggulan perintisan dan pemberdayaan kelompok KB Pria Vasektomi. Kasus di Badung adalah perolehan Srikandi
Award dari Kemenkes untuk bidan teladan dalam sosialisasi vasektomi. Metode yang digunakan adalah analisis kasus dengan teknik pengumpulan data wawancara mendalam dan FGD. Hasil penelitian adalah bahwa untuk meningkatan jumlah peserta KB Pria Lestari mereka menggunakan berbagai bentuk komunikasi pemasaran. Hal ini dilakukan untuk menciptakan opini dan perolehan perubahan perilaku. Penggunaan berbagai bentuk komunikasi pemasaran dalam mempromosikan produk di sebut komunikasi pemasaran terpadu.

\section{Teori Perencanaan Pesan (Charles Berger)}

Salah satu tujuan komunikasi dalam perspektif positivistik adalah mengubah sikap ataupun perilaku. Perspektif ini berpandangan bahwa melaui pesan maka sikap dan perilaku seseorang dapat diubah. Namun demikian mengubah sikap dan perilaku bukan persoalan yang sederhana. Komunikator perlu merencanakan atau mendisain strategi pesan, cara penyampaian, media yang digunakan agar pesan komunikasi menjadi efektif dan efisien untuk mencapai tujuan.

Charles Berger menawarkan Teori Rencana (Theory of Planning), sebagai salah satu teori yang cukup terkenal dalam ilmu komunikasi. Teori ini menjelaskan bahwa rencana adalah representatif kognitif secara hirarkhi dari urutan tindakan yang diarahkan pada tujuan. Dengan kata lain, rencana adalah gambaran mental (mental images) dari sejumlah langkah yang akan ditempuh untuk mencapai sesuatu tujuan. Langkah-langkah itu bersifat hirarkhi atau berjenjang karena tindakan tertentu harus dilakukan lebih dulu baru tindakan lain dapat dilakukan. Perencaan adalah proses menetapkan berbagai rencana tindakan (Morissan, 2009:115)

Banyak faktor yang mempengaruhi efektifitas dan efisiensi dalam proses komunikasi. Pertama, tingkat kesulitan pesan yang akan disampaikan. Kedua, tingkat pengetahuan dan pengalaman audien terhadap obyek yang akan diinformasikan. Ketiga, tingkat kebutuhan 
audiens akan informasi yang akan disampaikan. Keempat, opini publik (negatif atau positif) terhadap informasi pesan yang akan disampaikan. Dan masih banyak faktor lagi yang harus dicermati agar tujuan komunikasi tercapai.

Komunikasi disatu sisi merupakan bagian penting untuk mencapai tujuan. Namun demikian komunikasi merupakan proses tersendiri yang membutuhkan managerial dengan baik agar proses tersebut efektif dan efisien. Banyak komponen yang harus dipersiapkan yaitu komunikator, pesan, komunikan, media, noise. Masing masing komponen harus dicermati kelebihan dan kekurangan. Masing-masing komponen sama pentingnya karena masing-masing saling terkait dalam proses penyampaian pesan.

Keberhasilan komunikasi bersifat kontektual, yaitu dipengaruhi ruang dan waktu. Untuk itu keberhasilan rencana komunikasi dalam suatu kurun waktu atau pada wilayah tertentu belum tentu berhasil untuk diterapkan pada waktu atau kelompok yang berbeda. Jika akan menggunakan perencanaan yang sudah ada, agar tujuan komunikasi berhasil maka perencanaan tersebut harus diperbaharui disesuaikan dengan konteks yang ada.

Teori ini dipertajam oleh Barbara O'Keefe yang merumuskan Teori Logika Pesan (Message Design Logic Theory) untuk menjelaskan bagaimana proses berpikir yang terjadi sehingga muncul pesan (Morissan, 2009:119). O'Keefe mengemukakan tiga logika dalam merancang pesan yaitu: 1) Logika ekspresif, logika yang memandang komunikasi sebagai suatu cara untuk mengekspresikan diri dan menyatakan perasaan/pikiran. Pesan yang terdapat dalam logika ini adalah bersifat terbuka dan reaktif. Dalam hal ini, logika ekspresif bersifat selfcentered atau terpusat pada diri komunikator; 2) Logika konvensional, yaitu logika yang melihat komunikasi suatu permainan yang dimainkan dengan mengikuti sejumlah aturan dan norma yang diterima termasuk hak dan tanggungjawab masing-masing yang terlibat. Logika ini bertujuan merancang pesan yang sopan, pantas, sesuai norma yang berlaku dan disetujui kedua belah pihak; 3) Logika retorika, adalah logika yang memandang komunikasi sebagai suatu cara untuk mengubah aturan melalui negosiasi. Pesan yang dirancang bersifat lentur atau fleksibel, memiliki pemahaman yang terpusat pada lawan bicara. Komunikator cenderung membingkai ulang situasi yang dihadapi agar tujuan (termasuk persuasi dan kesopanan) dapat diintegrasikan dalam satu kesatuan yang bulat.

Dalam KIE metode vasektomi, pesan harus dirancang dengan kreatif agar pesan komunikasi efektif dan efisien. Tujuan akhir dari aktivitas ini adalah perubahan opini terhadap vasektomi dan perubahan perilaku.maka dari itu bentuk komunikasi yang cocok adalah persuasif. Pesan komunikasi harus berpusat pada komunikan yaitu masyarakat yang menjadi sasaran vasektomi. Untuk itu dalam merancang pesan komunikasi harus memperhatikan karakter dari khalayak sasaran. Pada penelitian ini khalayak sasaran adalah masyarakat pantai dengan tingkat kelahiran tinggi, hidup dalam kemiskinan, keyakinan agama sangat kuat.

\section{Teori Kemungkinan Elaborasi (Richard Petty \& John Cacioppo)}

Teori Kemungkinan Elaborasi (Elaboration Likelihood Theory) pada dasarnya adalah teori mengenai persuasi. Teori ini mencoba memperkirakan kapan dan bagaimana seseorang akan dapat atau tidak dapat pendapat atau perilakunya setelah mendapat terpaan informasi. Teori ini menjelaskan berbagai cara yang dilakukan orang ketika ia mengevaluasi informasi yang diterimanya. Terkadang seseorang mengevaluasi suatu informasi dengan cara yang rumit dengan menggunakan pemikiran kritis, terkadang menggunakan pemikiran yang sederhana. Terkadang orang sangat memikirkan argumen, namun terkadang tidak (Morissan, 2009:59). 
Menurut teori ini, cara orang memproses suatu informasi terdiri atas dua cara. Pertama, membawa informasi itu melalui jalur sentral (central route). Kedua, seseorang membawa informasi ke jalur pinggiran (peripherial route).

Jalur sentral, yaitu jalur yang membutuhkan pemikiran kritis (elaboration), sifatnya sangat mendetail atau rinci. Pada jalur ini seseorang secara aktif memikirkan informasi itu dan mempertimbangkankannya dengan memperhatikaninformasilain yang sudahdimiliki atau dicarinya. Seseorang mempertimbangkan dengan penuh hati-hati untuk sampai pada penerimaan informasi tersebut. Pada jalur ini dibutuhkan waktu panjang untuk menerima informasi. Hasilnya adalah perubahan pandangan bersifat lebih permanen dan biasanya diikuti oleh perubahan perilaku. Orang yang mempunyai keterlibatan tinggi pada suatu isu atau produk, kecenderungan akan menggunakan pemikiran kritis. Setiap informasi yang diperoleh akah dielaborasi sedemikian sehingga meyakinkan seseorang untuk menerima atau tidak menerima produk tersebut (setuju atau tak setuju terhadap isu). Orang yang punya keterlibatan tinggi pada produk tidak sekedar memperhatikan fungsi produk tetapi lebih berpikir kekhasan (nilai lebih yang membedakan) padai produk tersebut. Keunggulan dan kekurangan akan dikritisi sedemikian rupa untuk sampai tahap penerimaan. Dia tidak terpengaruh oleh aspek-aspek pemanis dari informasi. Jika informasi berbentuk iklan, seseorang tidak mudah dipengaruhi oleh layout iklan, tampilan iklan, penggunaan artis (lib service).

Jalur pinggiran, adalah jalur yang tidak membutuhkan pemikiran kritis(non-elaboration), sifatnya tambahan/bukan pokok. Seseorang yang mengolah informasi melalui jalur periferial biasanya kurang kritis terhadap informasi yang yang diterima. Dampaknya adalah perubahan yang terjadi bersifat temporal (sementara). Pengaruhnya terhadap perilaku juga minimal.
Orang yang mempunyai keterlibatan rendah terhadap suatu produk atau isu biasanya tidak menggunakan pemikiran kritis untuk sampai tahapan penerimaan informasi. Seseorang lebih terpengaruh oleh lib service dari penyampaian informasi seperti ketertarikan pada pada salesgirl yang cantik dan bukan berpikir nilai lebih dari suatu merk produk. Orang dalam keterlibatan rendah menganggap semua merek untuk jenis produk yang sama mempunyai fungsi yang sama.

Teori Elaborasi ini memberikan prediksi apakah seseorang akan memberikan pemikiran kritisnya terhadap produk atau isu atau tidak. Tingkat keterlibatan tinggi (kedekatan isu atau tingkat pentingnya produk) dapat memprediksi bahwa seseorang memberikan pemikiran kritisnya. Demikian sebaliknya, keterlibatan yang rendah pada produk dapat diprediksi bawa informasi yang disampaikan tidak akan dikritisi.

Selain tingkat keterlibatan, teori elaborasi juga bisa dipakai untuk memprediksi tingkat penerimaan berdasarkan tingkat resiko dari produk atau isu negatif yang menerpa produk. Produk dalam kategori tersebut akan melibatkan pemikiran kritis (elaborasi). Demikian sebaliknya, produk yang tak beresiko atau tidak sedang mengalami krisis image tidak membutuhkan pemikiran kritis untuk sampai pada tahapan penerimaa

Teori Elaborasi dapat digunakan untuk merancang pesan komunikasi. Jika keterlibatan calon audien terhadap produk atau tinggi maka hal-hal yang bersifat inti perlu ditonjolkan. Demikian halnya untuk produk-produk yang mempunyai resiko tinggu atau sedang dalam krisis image. Jika keterlibatan calon audience terhadap produk atau isu rendah maka aspek-aspek periferial dapat ditonjolkan.

Metode vasektomi yang mempunyai opini negatif merupakan produk yang menuntut calon pengguna menggunakan pemikiran kritis. Maka pesan-pesan yang akan disampaikan tidak bisa sekedar mengandalkan pada aspek-aspek periferial. Pesan harus dirancang pada sapek 
sentral yaitu menjawab opini negatif dari metode vasektomi. Penggunaan nara sumber seperti dokter, tokoh agama, testimoni pengguna adalah hal penting untuk menjawab aspek inti sepeerti pengebirian, haram, membuat tidak jantan.

\section{Teori Keseimbangan (Heider)}

Teori Keseimbangan (Balance Theory) memandang manusia selalu menjaga keseimbangan antara kepercayaan yang ada pada dirinya dengan evaluasi. Artinya orang akan mencari keseimbangan jika informasi yang diterimanya tidak sesuai dengan kepercayaan yang selama ini diyakininya. Dalam teori ini ada 3 elemen penting yang harus ada agar proses keseimbangan bisa tercapai. Elemen pertama adalah orang yang pernah merasakan, elemen kedua sikap terhadap objek, dan elemen ketiga adalan obyek lain yang berhubungan dengan obyek pertama (Sutisna, 2002:107)

Teori ini melihat bahwa pandangan negatif seseorang terhadap suatu objek atau pendapat bisa diubah dengan menghadirkan bukti positif pada obyek tersebut. Bukti positif bisa mereduksi penilaian negatif. Kepercayaan bisa dibangun yang pada akhirnya perilaku pun berubah seiring menguatnya kepercayaan. Teori ini bisa dipakai untuk membangun citra atau bahkan untuk memperbaiki situasi krisis kepercayaan.

Salah satu contoh penggunaan teori adalah saat salah satu produk susu kena isu lemak babi. Kepercayaan pasa produk susu formula jatuh. Salah satu cara yang diupayakan untuk memulihkan kepercayaan adalah memberikan bukti bahwa susu formula sudah bebas dari lemak babi. Para perancang pesan komunikasi mencoba cari tahu penyebab krisis. Ditemukan jawaban bahwa sumber krisis adalah lemak babi yang oleh kalangan muslim adalah hukumnya haram atau dilarang untuk dikonsumsi. Untuk mengembalikan kepercayaan para perancang komunikasi menggunakan otoritas yaitu para ulama. Saat itu para ulama diminta minum susu formula sebagai bukti bahwa susu formula sudah terbebas dari lemak babi. Upaya ini sangat berhasil dalam mengembalikan kepercayaan publik.
Teori ini dapat dipakai untuk membedah stategi KIE vasektomi yang mengalami kesulitan. Opini negatif tentang vasektomi harus dipetakan terlebih dahulu. Jawabannya adalah pendapat bahwa vasektomi tidak lain proses pengebirian sehingga mengganggu aspek kejantanan seperti tidak bisa ereksi, mengurangi kenikmatan. Isu negatif lainnya adalah aspek halal atau haram terhadap vasektomi. Isu negatif ini harus dijawab dengan pesan komunikasi yang meyakinkan dan dapat diterima. Penggunaan testimoni dan penjelasan ulama yang dipercaya bisa dipakai sebagai sumber informasi untuk membangun kepercayaan tersebut.

\section{Komunikasi Pemasaran Terpadu}

Pemasaran menurut definisi dari AMA (American Marketing Association) diartikan sebagai fungsi organisasi dan serangkaian proses menciptakan, mengomunikasikannya, dan menyampaikan nilai bagi para pelanggan sera mengelola relasi pelanggan sedemikian rupa sehingga memberikan manfaat bagi organisasi dan para stakeholdernya. Pemasaran (marketing) merupakan managemen dari beberapa komponen yang terkenal dengan marketing mix yaitu product, price, place, dan promotion (4P). Pada awalnya konsep pemasaran lebih berorientasi pada kepentingan produsen. Namun dalam perkembangannya pemasaran sebagai proses managemen lebih berorientasi pada kepentingan konsumen. Hal ini terjadi karena tingkat persaingan produk semakin tinggi dan konsumen semakain melek (kosmopolitan). Pada hakekatnya pemasaran adalah proses pertukaran yang dilakukan oleh dua belah pihak atas dasar kesepakatan atau persetujuan bersama.

Salah satu aktifitas penting dalam pemasaran adalah komunikasi pemasaran (promosi). Komunikasi pemasaran adalah proses menyampaikan informasi produk dari produsen pada konsumen. Melalui aktifitas ini maka paling tidak merek produk terinformasikan dan masyarakat menyadari akan keberadaan 
produk tersebut. Tingkatan selanjutnya, komunikasi pemasaran mampu mempersuasi calon konsumen menggunakan produk tersebut. Secara rinci fungsi komunikasi pemasaran adalah sebagai berikut: 1) Menginformasikan produk kepada masyarakat sehingga masyarakat menyadari keberadaan nama merek produk; 2) Menginformasikan keunggulan (kekhasan) suatu merek produk dengan merek produk lainnya yang sejenis (direfernsiasi produk); 3) Membangun sikap positip terhadap produk; 4) Mempersuasi calon konsumen untuk segera memakai produk; 5) Melakukan panggilan kembali ingatan konsumen merek produk; 6) Memelihara atau meneguhkan kepuasan dan loyalitas konsumen

Ditengah persaingan yang tinggi dan konsumen makin kosmopolit maka komunikasi pemasaran semakin memegang peranan penting bagi pemasar. Sebagus apapun produk kalau tidak terkomunikasikan dengan baik maka produk tersebut tidak akan mampu mempersuasi calon konsumen. Untuk itu komunikasi pemasaran mampu menyedot anggaran yang besar. Untuk itu komunikasi pemasaran harus direncanakan seefektif dan seefisien mungkin untuk mendapatkan hasil yang maksimal.

Dalam menghadapi persaingan, potisioning produk menjadi penting. Dengan positioning yang tepat maka merek produk akan mudah dikenal dan dihapal calon konsumen. Positioning yang tepat juga memudahkan menentukan target market. Keberhasilan menetukan potisioning produk dan target market akan memudahkan penyusunan pesan komunikasi.

Komunikasi pemasaran memiliki beragam bentuk, diantara personal selling, sales promotion, advertising, direct selling, dan public relation. Masing-masing bentuk komunikasi memiliki keunggulan dan kelemahan masing. Namun demikian tidak dapat tergantikan karena tujuan masing-masing berbeda. Untuk menghasilkan impact yang besar dari komunikasi pemasaran muncullah konsep baru yaitu bauran komunikasi pemasaran (promotion mix). Sebuah aktifitas yang mensinergikan semua bentuk komunikasi pemasaran untuk saling melengkapi.
Berdasarkan latarbelakang masalah tersebut, penelitan ini bertujuan untuk menganalisis implementasi integrated marketing communications vasektomi dalam upaya peningkatan akseptor KB pria lestari di Kota Pekalongan.

\section{Metode Penelitian}

Penelitian ini menggunakan pendekatan kuantitatif, sebuah perspektif yang melihat manusia sebagai makluk yang pasif. Perilaku dapat diubah dengan pemberian stimulanstimulan pesan yang diciptakan. Untuk itu perilaku manusia dapat digeneralisir. Menurut Cresswell (1994:5) penelitian kuantitatif memiliki karakteristik sebagai berikut :1) Realitas bersifat obyektif dan tunggal; 2) Realitas terpisah dengan peneliti (peneliti terpisah dari obyek penelitian); 3) bebas nilai; 4) proses penelitian bersifat deduktif; 5) sampling dan generalisasi hasil penelitian

Metode penelitian yang digunakan dalam penelitian ini adalah metode verifikatif, yaitu penelitian yang menguji teori atau hasil penelitian sebelumnya sehingga diperoleh hasil yang memperkuat atau memperlemah teori atau hasil penelitian sebelumnya itu. Penelitian ini mencoba memferifikasi hasil penelitian sebelumnya yang mencoba mengeksplorasi strategi kreatif KIE metode vasektomi dalam upaya meningkatkan akseptor $\mathrm{KB}$ lestari di Kota Surabaya Jawa Timur dan Kabupaten Badung Bali. Hasilnya adalah para komunikator (penyuluh) menggabungkan berbagai bentuk komunikasi pemasaran untuk membentuk opini positif tentang vasektomi dan perubahan perilaku yaitu kesediaan ikut vasektomi. Aktifitas yang dilakukan oleh para penyuluh di bidang pemasaran terkenal dengan komunikasi pemasaran terpadu. Pola penyuluhan ini akan diverifikasi tingkat efektif dan efisiensinya di daerah penelitian yang berbeda yaitu Kota Pekalongan.

Subjek penelitian adalah implementasi komunikasi pemasaran terpadu metode vasektomi di Kota Pekalongan. Adapun obyek peneltian adalah Tim KIE yang terdiri dari peserta KB pria vasektomi, tenaga penyuluh BKKBN setempat, tenaga medis, tokoh agama, dan masyarakat calon peserta. 
Data dikumpulkan dengan teknik eksperimen dan observasi. Menurut Mangkunegara (2012:51) eksperimen merupakan salah satu cara mengukur pengaruh situasi khusus terhadap sikap dan perilaku audience. Pengkondisisan situasi sengaja diciptakan dan direncanakan untuk melihat perubahan yang terjadi. Dalam penelitian bentuk dan cara KIE direncanakan dipersiapkan sedemikian rupa untuk mengetahui perubahan pengetahuan, sikap, dan perilaku masyarakat terhadap metode vasektomi. Sebelum KIE dilangsungkan semua sudah direncanaka mulai bentuk komunikasi yang dipakai, bahasa yang dipakai, cara menyampaikan pesan, cara menjawab pertanyaan.

Eksperimen dilakukan beberapa kali yaitu: pertama adalah penyuluhan dalam ruangan dimana antar penyuluh dan audience ada dalam ikatan yang kuat. Kedua adalah KIE ditempat umum yang dinamai gerebek pasar. Dalam kegiatan ini antar komunikator dan komunikan tidak ada ikatan yang kuat. Untuk itu komunikator dilengkapi dengan brosur. Kegiatan ini dilakukan di dua tempat yaitu car free day di alun-alun dan di pasar tiban sore hari di tepi jalan. Ketiga adalah komunikasi tatap muka.

Dari eksperimen tersebut maka langkah selanjutnya adalah mengevaluasi dari jalannnya eksperimen. Evaluasi dilakukan dengan FGD pada para tenaga penyuluh KIE dan FGD pada audience. Data yang dikumpulkan melalui FGD tenaga penyuluh adalah untuk mengetahui kelebihan dan kekurangan saat eksperimen yaitu mengimplementasikan komunikasi pemasaran terpadu pada saat KIE. Data juga dikumpulkan melalui FGD pada audience untuk mengetahui tingkat pengetahuan dan tingkat kepedulian audience terhadap metode vasektomi.

Data yang terkumpul dalam penelitian ini akan dianalisis dengan strategi analisis audit komunikasi (salah satu varian dari desain analisis kualitatif-verifikatif).

\section{Hasil Penelitian dan Pembahasan}

Partisipasi pria dalam pelaksanaan Program KB dan kesehatan reproduksi adalah masalah yang strategis dalam meningkatkan cakupan program KB dan kesehatan reproduksi. Partisipasi pria inilah yang kemudian terus ditingkatkan. Penetapan kriteria sasaran calon aksekptor KB pria vasektomi didasarkan pada beberapa hal, diantaranya orang yang melakukan vasektomi ditekankan yang berusia diatas 30 tahun, memiliki anak lebih dari 2 dan yang penting memiliki hubungan suami istri yang bagus dalam arti tidak ada masalah dan sudah sepakat untuk tidak ingin menambah jumlah anak lagi.

Kriteria ini merupakan kriteria umum yang digunakan untuk mengidentifikasi calon akseptor KB pria. Namun penambahan kriteria lain tidak tertutup kemungkinannya sesuai dengan kondisi suatu daerah. Tingkat sosial ekonomi masyarakat juga merupakan salah satu kriteria yang digunakan untuk menentukan sasaran $\mathrm{KB}$ pria. Keluarga dengan penghasilan cukup akan lebih mampu mengikuti program KB daripada keluarga yang tidak mampu, karena bagi keluarga yang kurang mampu KB bukanlah kebutuhan pokok. Masyarakat dengan tingkat ekonomi yang lemah biasanya belum aware dengan kontrasepsi, oleh karena itu cenderung memiliki anak yang banyak tanpa mempertimbangkan kemampuan untuk dapat menghidupi secara layak.

Kreteria tersebut diatas juga diterapakan di Kota Pekalongan, namun banyak hal yang menjadi kendala dalam penerapannya. Sebagai daerah dengan pertumbuhan ekonomi yang cukup pesat dan sebagai salah satu rujukan pendidikan agama islam sehingga dijuluki kota santri, kota Pekalongan bisa dikatakan sama dengan dengan kota-kota lain di jawa tengah terkait kepesertaan KB. Realisasi capaian peserta keluarga bencana atau KB aktif di wilayah kota Pekalongan, hingga saat ini baru mencapai 17,99 atau 924 orang dari jumlah target KB tahun 2016 ini. Realisasi 17,99 persen peserta $\mathrm{KB}$ aktif tersebut merupakan bagian dari capaian target peserta KB aktif pada 
2016 yang mencapai 5.137 peserta (www.rkb. pekalongankota.go.id). Jumlah peserta KB di wilayah Kota Pekalongan dalam setiap tahunnya memang terus terjadi peningkatan. Meski diawal tahun terkadang peningkatan jumlah peserta tidak terlalu signifikan, namun karena sosialisasi dan kesadaran masyarakat terhadap program tersebut diakhir tahun bisa mencapai target.

Realisasi target pencapaian peserta program keluarga berencana di wilayah Kota pekalongan hingga akhir tahun 2015, melampaui target yang ditetapkan 6.250 akseptor tercapai 113,06 persen, atau mencapai 7.066 akseptor KB. Peserta KB Metode Kontrasepsi Jangka Panjang atau MKJP mencapai 630 atau 24,55 persen dan non MKJP 1.936, dengan rician, pencapaian KB IUD sebesar 280 dari target 805 atau 34,78 persen. MOW tercapai 59 dari target 218 atau 27,6 persen, MOP 6 dari target 16 atau 37.5 persen. Sedangkan kondom tercapai 261 dari target 757 atau 37,48 persen. KB Implan dari target 864 tercapai 285 atau 32,99 persen/ pil dari target 1.137 tercapai 35030,73 persen. Yang paling banyak diminati masyarakat hingga saat ini adalah KB dengan metode suntik yang mencapai 99,03 persen dari target 1.338 telah tercapai 1.325.

Pencapaian tersebut didapatkan dari berbagai program yang dilakukan oleh BMP2AKB dan semua stakeholdernya. Program KIE yang paling seringdilakukanadalahkunjunganrutindarirumah ke rumah baik oleh Penyuluh KB ataupun kader. Kegiatan yang dilakukan sebelum melakukan kunjungan, terlebih dahulu tim mengadakan pra konseling yang bertujuan menentukan target yang sesuai dengan kriteria. Penentuan target ini berdasarkan hasil observasi dan masukan dari para kader. Sedangkan untuk penyuluhan massa masih menginduk pada kegiatan-kegiatan yang dilakukan oleh masyarakat, seperti PKK, Pengajian dan sebagainya, karena tidak adanya anggaran khusus untuk melakukan mobilisasi massa. Untuk kalangan remaja, sosialisasi juga dilakukan dengan mencari kegiatan yang sesuai dengan aktifitas mereka.
Peran serta kader dalam sosialisasi program $\mathrm{KB}$ juga relative tinggi, terlihat dari jumlah kader yang terdaftar di wilayah kota pekalongan yang cukup banyak. Dalam menjalankan perannya, para kader tidak hanya mengandalkan kegiatan-kegiatan tertentu, tetapi juga pada kegiatan sehari-hari. Kegiatan sosialisasi di lakukan dengan aktifitas sehari-hari ibu-ibu pada umumnya, misalkan aktifitas berbelanja, posyandu dan sebagainya.

Sosialisasi massa yang dilakukan di wilayah Kota Pekalongan, selain bertujuan meningkatkan pemahaman dan kepesertaan KB, juga bertujuan untuk meningkatkan peran serta pria. Berdasarkan data yang telah disebutkan diatas menunjukan peran serta pria sangat kecil sekali dalam program KB. Umumnya pria hanya menggunakan alat kontrasepsi berupa kondom, sedangkan vasektomi belum menjadi prioritas metode kontrasepsi pria. Ada banyak hal yang melatar belakangi hal ini, kendala utama yaitu masalah agama. Kota pekalongan yang dikenal sebagai kota santri, memiliki masayarakat dengan tingkat religiuitas yang tinggi, masih berpegang teguh pada prinsip agama yang tidak memperbolehkan melakukan tidakan penghambatan dalam memperoleh keturunan. Dukungan dari tokoh agama juga masih sangat kurang. Tokoh agama masih banyak yang belum sepakat dengan KIE sehingga masyarakat masih takut dalam hal kehalalan metode vasektomi ini.

Hal lain yang menjadi kendala metode vasektomi, yaitu pandangan masyarakat tentang vasektomi ini masih sangat tabu, sehingga masyarakat yang sudah melakukan vasektomipun masih malu-malu untuk mengakui bahwa dirinya adalah peserta KB vasektomi. Hal ini berkaitan juga dengan rumor yang berkembang dimasyarakat tentang akibat dari vasektomi yang dapat menyebabkan pria tidak jantan lagi dan sebagainya. Rumor tersebut belum terjawab, sehingga KIE yang rutin mutlak dilakukan untuk meluruskan stigma masyarakat tentang KB Vasektomi. 
Kendala yang terahir yaitu tentang kebijakan pemerintah kota pekalongan yang belum memprioritaskan Vasektomi sebagai metode kontrasepsi untuk pria. Hal ini juga disebabkan jumlah anggaran yang masih sangat kecil. Untuk melakukan tindakan vasektomi pemerintah hanya menyediakan biaya sebesar Rp. 250.000 per orang, padahal Perwalnya adalah RP 400.000, sehingga plafon yang ada tidak mencukupi. Biaya tersebut belum termasuk insentif yang diberikan kepada akseptor.

Implementasi KIE yang dilakukan pada wilayah Kota Pekalongan, mengadopsi metode yang ada di Kota Surabaya dan Badung, Bali. Kegiatan yang dilakukan yaitu dengan melakukan serangkaian sosialiasi KIE secara massa dan Gerebek pasar. Sebelum melakukan kegiatan tersebut, terlebih dahulu dilakukan koordinasi awal dengan berbagai unsur yang terlibat, seperti PLKB, Kader, akseptor KB, tokoh ulama, dan tenaga medis. Koordinasi yang dilakukan bertujuan untuk menentukan metode yang digunakan dan sasaran mana saja yang akan dituju. Hal ini merupakan aplikasi dari riset pasar dan segmentasi pasar dalam proses komunikasi pemasaran. riset pasar digunakan untuk menentukan strategi pemasaran dan faktor penentuan sedangkan segmentasi pasar yaitu menentukan pasar yang homogen dengan menyeleksi pasar yang ditentukan. Penentuan pasar ini penting karena kita tidak mungkin memasarkan suatu produk atau ide kepada semua kalangan.

Kegiatan pertama yang dilakukan yaitu KIE massa yang dapat dilakukan secara langsung maupun tidak langsung kepada masyarakat dalam jumlah besar. Kegiatan komunikasi, informasi dan edukasi dilakukan dengan memberikan penerangan massa melalui tatap muka langsung. Dengan penerangan, motivasi diharapkan meningkat sehingga terjadi peningkatan pengetahuan, perubahan sikap dan perilaku masyarakat dalam berKB khususnya vasektomi.
KIE pertama ini dilakukan di kelurahan Bandengan yang merupakan kawasan pesisir pantai dengan mayoritas penduduk bermata pencaharian sebagai nelayan. KIE ini menghadirkan narasumber dari tenaga medis, yaitu dokter yang bertugas melakukan tindakan vasektomi, tokoh ulama, dan akseptor vasektomi untuk memberikan testimoni terkait keikut sertaannya dalam vasektomi. Dalam KIE ini dijelaskan berbagai hal terkait vasektomi, dari apa itu vasektomi, kelebihan dan kekurangan serta bagaimana tindakan vasektomi dilakukan. Selain itu tokoh ulama menjelaskan pula vasektomi dari sisi agama, tentang bagaimana vasektomi dalam pandangan islam. Tujuan dari KIE ini adalah memberikan pemahaman yang benar baik sesuai medis ataupun non medis tentang Vasektomi. Metode yang digunakan dalam KIE disesuaikan dengan karakter masyarakat yang dituju. Ceramah dan testimoni masih menjadi metode utama. Ceramah yang dilakukan menggunakan bahasa yang sederhana yang mudah dipahami oleh masyarakat bahkan yang hanya lulusan Sekolah Dasar. Selain ceramah, penyampaian testimoni oleh akseptor juga menjadi bagian yang penting dalam memberikan keyakinan pada calon akseptor. KIE dengan motode ceramah seperti dibahas di atas, dilakukan lebih dari satu kali untuk semakin membuka pemahaman masyarakat dan memperluas target sasaran. selain itu KIE ini juga dilakukan untuk memetakan persoalan yang terjadi yang menjadi kendala dalam pelaksanaan program KB.

Dari hasil evaluasi yang dilakukan kepada masyarakat setelah KIE selesai dilaksanakan, diperoleh data bahwa penjelasan yang disampaikan oleh petugas mudah dipahami karena menggunakan bahasa yang sederhana dan disertai dengan ilustrasi menggunakan alat peraga. Sebelum KIE dilakukan, masyarakat mengungkapkan belum ada gambaran tentang apa sebenarnya vasektomi itu. namun setelah mendapat pelayanan KIE mereka menjadi paham dan mengerti, selain itu mereka bersedia menginformasikan perihal vasektomi ini kepada yang lain yang belum mendapat pelayanan KIE. 
Setelah KIE selesai dilaksanakan, selanjutnya tim yang dibentuk yang merupakan gabungan dari berbagai elemen, diantaranya penyuluh KB, Kader, akseptor dan beberapa unsur lain melakukan gerebek pasar. Gerebek pasar dilakukan untuk mendekati langsung calon akseptor. Dalam konsep komunikasi pemasaran, kegaiatan gerebek termasuk dalam Penjualan tatap muka (personal selling), yaitu penyampaian informasi produk secara face to face antara produsen (diwakili oleh salesman atau selesgirl) dalam hal ini adalah PLKB dan kader serta akseptor dengan konsumen potensial. Dalam kegiatan ini kunci keberhasilan terletak pada kemampuan mempersuasi dari para tenaga penjualan. Tujuan gerebek pasar bukan untuk mengajak masyarakat untuk langsung ikut MOP, namun untuk memberikan opini publik, dan supaya informasi cepat sampai.

Kegiatan gerebek pasar dipekalongan, dilakukan pada tempat yang banyak mendatangkan masyarakat, dalam hal ini dipilih pasar tiban yang aktifitasnya dimulai sore hari sekitar pukul 4 dan berahir menjelang maghrib. Pasar tiban yang terletak dijalan kartini ini menjadi tempat pertemuan antara penjual dan pembeli yang berasal dari berbagai wilayah di pekalongan. Tim melakukan sosialisasi langsung dengan mengajak berdialog masyarakat yang ditemui tentang seputar vasektomi dan juga membagikan flayer berisi informasi pendukung yang membantu untuk mengilustrasikan berbagai hal tentang vasektomi. Flayer yang dibagikan kepada masyarakat dalam komunikasi pemasaran termasuk dalam kategori periklanan yang merupakan kegiatan penyampaian pesan produk memalui media, dalam hal ini media lini bawah (below the line). Selain itu informasi tentang kegiatan gerebek dan vasektomi juga disampaikan melalui pengeras suara pada mobil pelayanan yang berkeliling diseputaran pasar tiban tersebut.

Kegiatan serupa juga kembali dilakukan pada aktifitas pasar tiban. Kali ini yang dipilih adalah kegiatan car free day pada hari minggu yang berpusat di alun-alun Kota Pekalongan. Skala acara ini hampir 3 kali lipat dari pasar tiban di jalan kartini. Treatmen yang dilakukan juga hampir sama seperti yang dilakukan pada gerebek sebelumnya. Sasaran dari kegiatan gerebek ini lebih luas, tidak hanya pengunjung car free day tetapi juga petugas-petugas yang terlibat dalam acara tersebut seperti satpol PP, Polisi dan sebagainya. Indikator keberhasilan dari kegiatan gerebek ini bisa dilihat dari antusiasme masyarakat dalam menerima dan menanggapi informasi yang disampaikan para petugas.

Dari rangkaian kegiatan tersebut, hasil yang didapatkan cukup efektif. Terbukti dari adanya peningkatan kepesertaan MOP. Kegiatan ini berhasil menjaring kurang lebih 6 calon akseptor yang berminat untuk melakukan vasektomi, dari yang biasanya hanya satu orang saja yang di dapatkan dari kegiatan penyuluhan sebelumnya. Selain itu pemberian insentif untuk masyarakat yang mau untuk melakukan vasektomi juga merupakan daya tarik lain, yang dalam komunikasi pemasaran merupakan promosi penjualan (sales promotion), yaitu upaya memberi nilai lebih pada produk yang dijual untuk menciptakan tindakan segera.

\section{Simpulan}

Implementasi strategi Komunikasi Pemasaran Terpadu pada program KIE Vasektomi mendapatkan tanggapan positif baik dari pemangku kepentingan maupun masyarakat sebagai sasaran KIE. Pemangku kepentingan (BPMP2KB Kota Pekalongan) yang mengorganisasi Tim KIE mendapatkan strategi baru dalam KIE vasektomi. Instansi ini sebelumnya selalu berpikir bahwa vasektomi sulit diterima masyarakat Kota Pekalongan. Alasan utama mereka adalah faktor agama. Untuk itu mereka tidak menetapkan target kepesertaan. Akibatnya selama ini BPMP2KB Kota Pekalongan tidak melakukan upaya atau strategi khusus dalam upaya meningkatkan kepesertaan vasektomi. 
Pada dasarnya para komunikator (PLKB, kader, peserta vasektomi, tenaga medis) memaknai metode vasektomi sebagai suatu upaya yang positif, terutama dalam peningkatan reproduksi wanita. Mereka menyadari bahwa banyak perempuan yang tidak cocok menggunakan KB hormonal, faktor tidak tertib jadwal, juga era emansipasi. Mereka menyadari bahwa penerimaan informasi dan perubahan perilaku pria untuk vasektomi bukan pekerjaan mudah. Kurangnya pemahaman vasektomi oleh masyarakat, opini negatif tentang vasektomi, dan faktor agama menjadi faktor penghambat dalam KIE vasektomi

Implementasi Komunikasi Pemasaran Terpadu pada Program KIE ini disambut positif Tim KIE vasektomi. Mereka berharap kegiatan semacam ini diprogramkan oleh BPMP2KB Kota Pekalongan sehingga kegiatan terencana, terarah dan hasilnya bisa optimal. Mereka sadar bahwa apa yang ditakutkan selama ini bahwa KIE vasektomi akan ditentang oleh masyarakat tidak terbukti. Hadirnya tokoh agama menjadi kunci terbentuknya opini positif publik tentang vasektomi. Tim KIE Kota Pekalongan juga mengetahui bahwa vasektomi bisa diterima masyarakat harus di mulai dari penciptaan opini public terlebih dulu. Sedangkan untuk perubahan perilaku diperlukan teknik komunikasi face to face.

\section{Daftar Pustaka}

Achmad, A.S. \& S.S. Ecip (penyunting). (1985). Komunikasidan Pembangunan. Jakarta: Sinar Harapan Atmoko, W., Vasektomi Metode Kontrasepsi Pria Efektif,Cepat,Aman, danMudah.Diakses dari http://www.jurnalmedika.com/edisiterbaru Bungin, Bungin. (2007). Penelitian Kualitatif: Komunikasi, Ekonomi, Kebijakan Publik, dan Ilmu Sosial Lainnya. Jakarta: Kencana Prenada Media Group.
Bryson, John M. (2007). Perencaan Strategis bagi Organisasi Sosial (terj). Yogyakarta: Pustaka Pelajar. Creswell, John W. (1994). Research Design Qualitative \& Quantitative Approach. California: Sage Publications. Craig, Robert T. (2007). Theorizing Communication Readings Across Tradition. Los Angeles: Sage Publication Denzin, Norman K. \& Yvonna S. L. (2009). Handbook of Qualitative Research (terj). Yogyakarta: Pustaka Pelajar. Griffin, EM. (2006). A First Look At Communication Theory. Boston: Mc Graw Hill. Hardiani, R. S., \& Pertiwi, M. A. (2013). Pendidikan Kesehatan Terhadap Sikap Suami Tentang Vasektomi. Jurnal Keperawatan Maternitas, 1(2). Kayo, Michael. (1994). Communcation Management. Sydney: Prentice Hall. Kuhnke, Elizabeth. (2013). Communication Skill for Dummies. West Sussex: John Willey and Sons Ltd. Littlejohn, Stephen W. \& Karen A. Foss. (2009). Encyclopedia Of Communication Theory. California: Sage Publication. Locker, Kitty O \& Stephen Kyo Kaczmarek. (2014). Business Communication: Building Critical Skills. New York : Mc Graw-Hill/Irwin Mangkunegara, Anwar Prabu. (2012). Perilaku Konsumen. Bandung: Refika Aditama Morissan \& Andy Corry Wardhany. 2009. Teori Komunikasi tentang Komunikator, Pesan, P e r c a k a p n, dan Hubungan. Bogor: Ghalia Indonesia Patterson, Sally J \& Janel M. Radtke. (2009). Strategic Communications for Nonprofit Organizations: Seven Steps to Creating a Successfull Plan. New Jersey: John Wiley \& Sons. 
Purwanti, H. (2011). Upaya Peningkatan Partisipasi Pria Dalam Keluarga Berencana Dan Kesehatan Reproduksi Sebagai Wujud Kesetaraan Gender. Jurnal Argumentum, 10(2), 153-169.

Smeltzer, Larry \& John Waltman \& Donald Leonard. (1991). Managerial Communication a Strategic Approach. M a s s a chusett: Ginn Press. Sukeni, N. N., \& MSi, S. H. (2009). Hegemoni Negara Dan Resistensi Perempuan Dalam Pelaksanaan Program
Keluarga Berencana Di Kecamatan Tejakula Kabupaten Buleleng Bali. Sutisna. (2002). Perilaku Konsumen Komunikasi Pemasaran. Bandung: Remaja Rosdakarya Wahyuni, N. P. D. S. (2013). Hubungan Pengetahuan Dan Sikap Akseptor KB Pria Tentang Vasektomi Serta Dukungan Keluarga Dengan Partisipasi Pria Dalam Vasektomi (Di Kecamatan Tejakula Kabupaten Buleleng). Jurnal Pendidikan Kesehatan Universitas Sebelas Maret, 1(1), 13501. Waldron. Vincent R. (2012). Communicating Emotion at Work. Cambridge: Polity Press 